\title{
Profetismo e resistência ao poder clerical num movimento feminino do séc. XII: luzes para o papel eclesial da mulher em tempo de pós-
} pandemia

\author{
Prophetism and resistance to clerical power in a women \\ movement of the Twelfth Century: enlightenment for the \\ ecclesiastical role of women in a post-pandemic period
}

Edelcio Serafim OTtaviani a

\section{Resumo}

O presente artigo é um exercício de reflexão em tempo de isolamento social, para pensar a ação pastoral da Igreja pós-pandemia e o papel das mulheres num processo de evangelização cada vez mais envolvido com o ambiente virtual. Dividido em duas partes, analisa primeiramente, com o auxílio de outros saberes, a tripla crise (pandêmica, eclesial e econômico/política) em que vive a Igreja Católica e problematiza a ênfase dada à celebração eucarística virtual, médium de uma pastoral de manutenção, por meio da qual mais uma vez é obnubilado o papel evangelizador das mulheres. Num segundo momento, ao seguir a estratégia contemporânea de José Comblin e Michel Foucault — que vão ao passado em busca de luzes para responder aos problemas de hoje — retoma a polêmica em torno do movimento das beguinas, como forma de tornar evidente os mecanismos de sujeição do clericalismo patriarcal há muito presente na estrutura eclesial. Por fim, associa as intuições do Beguinato às propostas pastorais contidas nos documentos preliminares ao Sínodo da Amazônia (Documento Preparatório e Instrumentum Laboris), como forma de instauração de um discipulado de iguais, capaz de interceptar o colonialismo e o patriarcalismo, que dão sustentação ao sistema injusto em que vivemos.

Palavras-chave: Pandemia. Resistência. Profetismo. Discipulado de iguais. Beguinato.

\footnotetext{
a Pontíficia Universidade Católica de São Paulo (PUC-SP); Centro Universitário Assunção (UNIFAI), São Paulo, SP, Brasil. Doutor em Filosofia, e-mail: eottaviani@pucsp.br
} 


\section{Abstract}

This article is an exercise of reflection in a time of social isolation, to think about the pastoral action of the post-pandemic Church and the role of women in a process of evangelization increasingly involved with the virtual environment. It is divided into two parts and analyses firstly, with the aid of other branches of knowledge, the triple crisis (pandemic, ecclesial and economic/political), in which the Catholic Church lives and problematizes the emphasis given to the virtual Eucharistic celebration, medium of a maintenance pastoral, through which once again the evangelizing role of women is obscured. In a second moment, and following the contemporary strategyie of José Comblin and Michel Foucault - who go to the past in search of lights to respond to today's problems -it reassumes the polemics around the movements of the Beguines, as a form of making evident the mechanisms of subjection of patriarchal clericalism has long been present in the ecclesial structure. Finally, it associates the intuitions of the Beguinage to the pastoral proposals contained in the preliminary documents to the Amazon Synod (Preparatory Document and Instrumentum Laboris), as a way of stablishing a discipleship of equals capable of intercepting the colonialism and patriarchy, that sustain the unjust system in which we live.

Keywords: Pandemic. Resistance. Prophetism. Discipleship of equals. Beguinage.

\section{Introdução}

Num primeiro momento, este texto tem por objetivo problematizar o estatuto da mulher na estrutura eclesial durante o isolamento social e no período pós-pandemia. Aponta para a tríplice crise em que nos encontramos (pandêmica, eclesial e econômico/política) e discorre sobre as pistas oferecidas nos documentos preliminares ao Sínodo da Amazônia (Documento Preparatório e Instrumentum Laboris) para saída do colonialismo, do patriarcalismo e dos pressupostos capitalistas que estão na base do sistema neoliberal, cujas fragilidades foram colocadas aos olhos do mundo mediante o colapso dos diferentes sistemas de saúde, no combate à pandemia do novo Coronavírus Covid-19.

Num segundo momento, mostra os principais elementos da resistência à dominação clerical desenvolvida por um movimento feminino do final do século XII, denominado Beguinato, em francês Béguinage, cuja espiritualidade libertadora deixou marcas profundas na alta Renânia nos dois séculos seguintes e influenciou a cultura religiosa dos Países Baixos até o século XX. Ele parte dos estudos de José Comblin (1923-2011) e de Michel Foucault (1926-1984), em seus esforços de perscrutar no passado a inspiração para possíveis saídas aos entraves colocados pelas estruturas de poder no momento atual; aplica a noção de arcaico, 
desenvolvida por Giorgio Agamben (1942) no texto O que é o contemporâneo? (2009, p. 55-73) ${ }^{1}$, para pensar um novo estatuto da mulher, nos organismos de decisão da estrutura eclesial, por meio dos quais se efetivam as diretrizes da ação pastoral.

Na conclusão, estes elementos nos permitem afirmar que, no âmbito da estrutura eclesial, a ação das beguinas, associada à análise do estatuto da mulher na Igreja da Amazônia, presente no Documento Preparatório e no Instrumentum Laboris, pode ser a motivação para pensar um novo papel da mulher na Igreja e, com ele, a abertura de espaço para práticas de evangelização promissoras, presenciais e até mesmo virtuais, dentro e fora das estruturas eclesiais, que apontem saídas para a profunda crise em que nos encontramos.

\section{O contexto atual e o papel das mulheres na pastoralidade da Igreja}

A pandemia do novo coronavírus colocou-nos todos num estado de guerra. Há quem denuncie essa aproximação metafórica da Covid-19 com os conflitos que marcaram a primeira metade do século $X X$, como a jornalista Juliana de Albuquerque (2020), no rastro da escritora americana Susan Sontag. Ao seguir as reflexões de Sontag em "Doença Como Metáfora" (1978) e "Aids e Suas Metáforas" (1989), Albuquerque chama a atenção para os aspectos políticos e morais ligados à enfermidade e a aproxima da opinião da jornalista Emily Maitlis da BBC de Londres, para quem a linguagem em torno do Covid-19 é banal e enganosa. Esta última "denuncia a atitude das lideranças políticas e comunitárias que ora minimizam os riscos da atual pandemia - comparando-a de modo irresponsável a uma gripe comum $-^{2}$, ora tentam convencer de que a pandemia deverá afetar a

\footnotetext{
${ }^{1}$ Nesse pequeno mas instigante texto, Giorgio Agamben diz que o contemporâneo é aquele que no escuro de seu tempo é capaz de ver as luzes que brilham nele, ao mesmo tempo que percebe, naquilo que é luminoso aos olhos de homens e mulheres de sua época, os seus aspectos sombrios. Intempestivo, aos moldes de Nietzsche, o contemporâneo se volta também para o passado (arcaico) para nele encontrar a arché, o princípio, a inspiração para a realização de algo novo no presente.

2 Em meio ao início da pandemia do novo Coronavírus Covid-19, no dia 24 de março de 2020 em rede nacional, o Presidente Jair Bolsonaro fez um pronunciamento televisivo contra as medidas dos governadores de estarem decretando o distanciamento social horizontal como forma de conter a
} 
todos de igual modo, como se ricos e pobres usufruíssem da mesma segurança em relação ao momento" (apud ALBUQUERQUE, 2020). Além do mais, diz Albuquerque, tais metáforas, utilizadas também por Angela Merkel $^{3}$ e associadas à denominação "gripe chinesa", fomentam uma linguagem que incita à discriminação dos povos e coloca os profissionais da saúde na linha de frente no "combate" à doença, como se fossem soldados prontos a sacrificar suas vidas pelo nosso bem-estar.

\section{Uma crise dentro da crise}

Não obstante esse alerta, muito oportuno por sinal, outras metáforas utilizadas nos forçam a pensar necessariamente num estado belicoso instaurado contra um inimigo silente que não tem uma materialidade visível a olho nu, muito menos gosto e cheiro. Inimigo este que está a todo momento perto e enganosamente distante de nós. Plataformas virtuais de reuniões ministeriais comparadas a "Gabinete de Guerra", no Reino Unido, "Orçamento de Guerra" proposto pela Emenda à Constituição (PEC 10/2020), no Brasil, "Hospitais de Campanha" em várias capitais brasileiras e cidades do interior, para atender os doentes acometidos do Covid-19, todas essas expressões nos remetem, queiramos ou não, a estratégias e ambientes que lembram uma situação de guerra, muito embora hospitais de campanha sejam montados também em áreas onde ocorreram desastres naturais. Por outro lado, nem toda metáfora precisa necessariamente ser veiculada de forma negativa, pois a expressão "Hospital de Campanha" foi apresentada pelo Papa Francisco em sua primeira grande entrevista ao jornalista e padre jesuíta Antonio Spadaro do seguinte modo:

disseminação da doença. Segundo ele, tais medidas são desmesuradas frente ao que não passa, para quem é sadio (atleta) como ele, de uma simples "gripezinha", menosprezando a gravidade da doença (Cf. BRITO, Ricardo. Bolsonaro volta a se referir ao coronavírus como gripezinha, critica governadores e gera reação. 24 mar. 2020. Disponível em: https://economia.uol.com.br/noticias/reuters/2020/03/24/bolsonaro-volta-a-se-referir-ao-coronaviruscomo-gripezinha-e-criticar-governadores-por-restricoes.htm?. Acesso em: 22 mai. 2020).

${ }^{3}$ Em seu "Discurso ao povo alemão ante a situação do Coronavírus". Merkel diz o seguinte: "Desde la reunificación alemana, no, desde la segunda guerra mundial, no ha habido un desafío más grande para nuestro país que dependiera tanto de nuestra acción mancomunadd" (MERKEL, 2020, p. 87). 
Vejo com clareza que aquilo de que a Igreja mais precisa hoje é a capacidade de curar as feridas e de aquecer o coração dos fiéis, a proximidade. Vejo a Igreja como um Hospital de Campanha depois de uma batalha. É inútil perguntar a um ferido grave se tem o colesterol ou o açúcar altos. Devem curar-se suas feridas. Depois podemos falar de todo o resto. Curar as feridas, curar as feridas... E é necessário começar de baixo (FRANCISCO apud SPADARO, 2013, p. 19).

No que toca à atitude da Igreja frente aos mais necessitados, se o apelo do Papa Francisco ainda não surtiu o resultado esperado, tirando-nos da acédia ${ }^{4}$, certamente o Covid-19 vai nos obrigar a nos reinventar, a descobrir formas de atendimento aos fiéis que ultrapassem a pastoral de manutenção.

Um mês após o isolamento social, que levou também as Igrejas a fecharem suas portas, um pequeno vídeo começou a circular nas redes sociais, intitulado "Por favor, devolvam-nos a Santa Missa"5. Nele se apresentam jovens, em sua maioria brancos, fazendo um apelo aos bispos para que a missa seja de novo realizada presencialmente, comprometendo-se a higienizar os espaços e a cuidar para que os fiéis não sejam contaminados pela doença. O pleito desse movimento foi referendado posteriormente por meio de uma carta intitulada "Apelo para a Igreja e para o mundo", datada de 07 de maio do corrente ano e assinada - dentre teólogos, médicos, virologistas e investigadores - por D. Carlo Maria Viganò, Núncio Apostólico emérito dos Estados Unidos, Cardeal Gerhard Ludwig Muller, Prefeito emérito da Congregação para a Doutrina da Fé, Cardeal Robert Sarah, Prefeito da Congregação para o Culto Divino e Disciplina para os Sacramentos todos ultraconservadores, aparentemente inseridos num movimento global contrário às linhas mestras do papado de Francisco. Chama a atenção, no texto da carta, o seguinte parágrafo:

Por este motivo, como Pastores, reivindicamos firmemente o direito de decidir autonomamente sobre a celebração da Missa e dos Sacramentos, assim como pretendemos absoluta autonomia nos assuntos que sejam da nossa imediata jurisdição, como as normas litúrgicas e os métodos de administração da Comunhão e dos

\footnotetext{
${ }^{4}$ O Papa Francisco retoma o sentido desta palavra, presente na Exortação Apostólica Gaudete et Exultate, sobre a chamada à Santidade no mundo atual, e o direciona, numa carta, aos presbíteros por ocasião dos 160 anos de morte do Santo Cura D'Ars: "Peçamos e façamos pedir ao Espírito que 'venha despertar-nos, dar-nos um abanão na nossa sonolência, libertar-nos da inércia. Desafiemos a habituação, abramos bem os olhos, os ouvidos e sobretudo o coração, para nos deixarmos mover pelo que acontece ao nosso redor e pelo clamor da Palavra viva e eficaz do Ressuscitado'" (GE, n. 137 apud FRANCISCO, 2019).

${ }^{5}$ Disponível em: https://www.youtube.com/watch?v=WIW5_uwlrDs. Acesso em: 22 mai. 2020.
} 
Sacramentos. O Estado não tem direito algum de interferir, por qualquer motivo, na soberania da Igreja ${ }^{6}$.

Por meio desses manifestos, prelados, intelectuais e leigos insistem para que sejam eliminadas as proibições à celebração pública dos serviços religiosos. O que chama a atenção nessa carta é o tom alarmante, dirigido não aos efeitos da pandemia, mas a uma conspiração instaurada por um governo mundial - sem nome, sem rosto e isento de qualquer controle. Segundo a carta, esse governo mundial, por meio de uma "odiosa tirania tecnológica", decide o destino do mundo, confinando a todos a uma realidade virtual (Cf. VIGANÒ et al., 2020). Não nos ateremos ao teor da carta, que mescla implicitamente críticas de filósofos contemporâneos a respeito da sociedade de controle - do porte de Michel Foucault e Gilles Deleuze - a ideias conservadoras que não têm outro intento senão manter as prerrogativas do poder pastoral (clerical). Mas, procuramos salientar como ela reivindica no final, para além de todo o sentido de coresponsabilidade alertado, por exemplo, por Angela Merkel, "o direito [da Igreja] de decidir autonomamente sobre celebração da Missa e dos Sacramentos".

Por outro lado, no tocante à utilização das redes sociais para manter os serviços religiosos, Rafael Luciani (2020, p. 1) nos lembra que o período de quarentena, antes de ser um obstáculo à presença real do Cristo em meio ao Povo de Deus (Celebração Eucarística), é o tempo propício para jejuar do pão e aprender a comungar da Palavra. Deixando de lado os ultraconservadores, por estar consciente de que a privação das celebrações presenciais é uma necessidade que se impõe em decorrência do isolamento social, para não colapsar o sistema de saúde, Luciani, numa análise perspicaz, alerta para o fato de não somente padres, mas também bispos e arcebispos, terem substituído sem mais a celebração eucarística por sua visualização virtual sem a presença de fiéis, reforçando o clericalismo que, em meio a uma doença que afeta toda a humanidade, parece não ter outra ação pastoral do que a oferta da prática sacramental. Em seu artigo, o teólogo relembra todo o esforço do Concílio Vaticano II em superar a liturgia

\footnotetext{
${ }^{6}$ Disponível em: http://www.diesirae.pt/2020/05/apelo-para-igreja-e-para-o-mundo.html. Acesso em: 22 mai. 2020. NA. No mesmo dia, o Cardeal Sarah quis retirar a sua assinatura, mas já era tarde. Viganò já a havia difundido a variados meios de comunicação, espalhando-se pelo mundo (cf. TOSATTI, Marco. Sarah signs the appeal, then revokes. The way it happened. 05 mai. 2020. Disponível em: https://www.marcotosatti.com/2020/05/08/sarah-signs-the-appeal-then-revokes-the-way-ithappened/. Acesso em: 22 mai. 2020).
} 
tridentina, que tornava prática comum a missa sem o povo, para reevocar a eclesiologia do Povo de Deus, presente no segundo capítulo da Constituição Dogmática Lumen Gentium (2012a, p. 112-126), em união à reforma litúrgica anunciada pela Sacrossantum Concilium (2012b, p. 35-41) que tratou dos presbíteros como parte do Povo de Deus ao presidirem a Eucaristia (Cf. SC, ns. 11, 26, 48; LG, n. 10). Ao falar da crise pela qual passa a Igreja, com o crescente esvaziamento dos templos na Europa e no Continente americano - acrescida agora de um segundo grau por causa da pandemia -, Luciani nos exorta a não repetir modelos tridentinos, que não nos ajudam a formar e a viver uma fé adulta, mas a colocar em prática o ofício divino das comunidades, a leitura comentada das Sagradas Escrituras e a assistência aos pobres. Serviço tão necessário nos dias de hoje, posto serem estes as maiores vítimas da injustiça social e dos efeitos amargos, ainda que necessários, do isolamento social. Ainda sobre o prisma da crise em segundo grau, Luciani nos recorda que as reformas da Igreja, instauradas pelo Concílio Vaticano II, são "espirituais, pastorais e institucionais", devendo tocar as mentalidades, as práticas e as estruturas eclesiais, e acrescenta: "se nos segue movendo o clericalismo, só estaremos mudando as formas - agora virtuais, mas não o fundo" (LUCIANI, 2020, p. 24). Se não houver uma conversão da instituição eclesiástica, quando a pandemia passar, seguiremos com os mesmos problemas pastorais decorrentes de uma mentalidade patriarcal e clericalista. Ao centralizar-se na reinvindicação da celebração eucarística, o movimento "devolva-nos a Santa Missa" e o "Apelo para a Igreja e para o mundo" procuram manter um status quo onde os jovens que aparecem nos vídeos não fazem mais do que conservar o papel dado às mulheres no interior da igreja até então: o de simples coadjuvantes, mas não de protagonistas da ação evangelizadora.

Por ora, vale lembrar que não basta também, como o quer José Antonio de Almeida (2019), ao refletir sobre a possibilidade de ordenação de mulheres para tornar presente a Eucaristia em comunidades isoladas da Amazônia, mostrar que não há impedimentos nem pastorais nem teológicos a ela. A luta tem que ser na verdade contra o clericalismo. Se as mulheres vierem a ser um dia integradas ao sacerdócio, o que só não foi feito por causa de um "regime de verdade" instaurado pelo patriarcalismo desde os primórdios da Igreja, elas deverão fazer todo o esforço para resistir aos mecanismos clericais de controle e à cadeia de sujeições instituídas 
pelo pastorado no interior da estrutura eclesial, denunciados por Michel Foucault em seu curso Segurança, Território, População (1978).

\section{Uma crise em terceiro grau}

Não desejo desanimar ninguém ao trazer à baila o aporte de Boaventura de Sousa Santos para analisar o panorama de crise instaurado pelo Covid-19, mas toda análise de conjuntura que se quer realista está no limiar de uma visão pessimista. É o que pensava o teólogo belga, radicado no Brasil, José Comblin, tratado por muitos bispos de negativista. O sociólogo português, ao se associar a tantos outros pensadores, que procuram refletir durante o significado desta pandemia no momento atual, nos oferece seu texto como um entre outros escudos permitindo-nos focar indiretamente e cortar a cabeça da Medusa que nos ameaça petrificar. Em "A cruel pedagogia do vírus" (2020), Souza Santos chama a nossa atenção para o que sucederá após havermos passado pelo estado de pandemia causado pelo novo coronavírus. Aliás, diz ele, não se trata de algo posterior a uma crise, mas de um acontecimento que somente agrava uma crise na qual estamos imersos já faz algumas décadas. Segundo ele, desde que o neoliberalismo se apresentou como sistema econômico hegemônico, desmontando as bases do Estado de Bem-estar social, e se fez presente em múltiplas nações situadas nos cinco continentes, vivemos num estado crítico permanente que serve de desculpa para que sejam feitos todos os cortes em políticas sociais (saúde, educação, previdência social) e se instaure legalmente a degradação dos salários (Cf. SOUSA SANTOS, 2020, p. 5). Esta crise permanente, instaurada para jamais ser resolvida, tem um duplo objetivo: legitimar a escandalosa concentração de riquezas e boicotar medidas que venham a evitar a eminente catástrofe ecológica. Nos quatro capítulos de seu inquietante opúsculo, Boaventura de Sousa Santos, dentre outros aspectos, procura mostrar o fato de os sistemas de saúde estarem hoje muito menos preparados para enfrentar essa pandemia do que há dez ou vinte anos atrás. A falta de Equipamentos de Proteção Individual (EPIs) de qualidade e dos instrumentos e medicamentos necessários para atender a população mais pobre é só um exemplo. O Sistema Público de Saúde, não só no Brasil, mas em outras partes do mundo, tem sofrido uma retração de investimentos, contribuindo para sua deterioração. A pandemia do Covid-19 só veio a agravar este estágio. 
Não obstante o sofrimento que essa pandemia tem causado, ceifando um número cada vez maior de vidas num curto período de tempo, o sociólogo português aponta para o lado positivo do distanciamento social, que nos fez ver que há coisas e situações melhores, e que nos fazem sentir bem (ficar em casa, ler um bom livro e passar mais tempo com os filhos), para além do redemoinho alucinante da cultura do consumo e do descarte. Partindo dos efeitos nefastos causados pela invisibilidade do vírus, que não sabemos onde está e em que hora ele pode se instalar em cada um de nós, Boaventura de Sousa Santos chama a nossa atenção para a invisibilidade do mercado. Lançando mão da fábula do unicórnio, interpretada por Leonardo da Vinci, o sociólogo português associa a intemperança e a incapacidade de se dominar, próprias a esse ser lendário, a três modos de dominação que passaram a imperar no mundo a partir do século XVII: o capitalismo, o colonialismo e o patriarcado. Segundo ele, esses são os três unicórnios contemporâneos que, longe de serem entidades separadas, agem, se alimentam e se fortalecem conjuntamente. No que se refere ao capitalismo, mostra a sua plasticidade no fato de ter hibernado na antiga União das Repúblicas Soviéticas (URSS) e de ter agido no interior do seu maior inimigo, o comunismo, como é o caso da China. Quanto ao colonialismo, mostra sua nova roupagem por meio do imperialismo econômico que se enraíza nos cinco continentes ditando regras aos Estados e conduzindo a conduta de suas populações. Em se tratando do patriarcado, à revelia das conquistas feministas das últimas décadas, ele mostra sua vitalidade no aumento da violência doméstica, da discriminação sexista e do feminicídio (Cf. SOUSA SANTOS, 2020, p. 12). Porém, tal qual o unicórnio da fábula, que tem sua fraqueza no amor pelas donzelas e se faz capturar no seio de uma delas pelos caçadores, essas três entidades têm também suas fragilidades. É nesse sentido que ele apela aos intelectuais para que auxiliem o povo, que sofre os revezes de sua dominação, a identificar a fraqueza de cada uma para, enfim, combatê-las na sua raiz.

Por fim, ao analisar os grupos para os quais essa quarentena se apresentará mais difícil (as mulheres, os trabalhadores precários ditos autônomos, o povo da rua, os moradores das periferias pobres das cidades, refugiados, imigrantes, deficientes e idosos), Sousa Santos mostra também como a pandemia colocou às claras, por meio das telas de televisão e das mídias eletrônicas, a injustiça, a discriminação e a exclusão sociais e o sofrimento que elas provocam (2020, p. 21). 
Associando a crise da pandemia à crise ecológica, ele aponta para o fato de que ambas são discriminatórias, no que tange à prevenção, a expansão e à mitigação, resvalando num darwinismo social. Fato é que grande parte da população não tem condições de seguir rigorosamente as prescrições da Organização Mundial de Saúde (OMS), seja por que está privada até mesmo de água e sabão, seja porque é obrigada a viver apinhada em espaços exíguos nos cortiços ou nas favelas. A pandemia veio nos mostrar que o sistema neoliberal, tão defendido por grande parte dos governantes atuais, não oferece um futuro positivo à maior parte da população mundial. Adotado pelos Estados, o modelo empresarial, sob a divisa de maiores lucros às custas dos menores investimentos possíveis, tem se apresentado como o novo deus demonizando o serviço público e com ele os princípios de cidadania e os direitos humanos. A quarentena veio nos mostrar que, mesmo e apesar da crítica de Giorgio Agamben à máquina estatal, a volta ao Estado de Bemestar social e à Comunidade é hoje a única saída da submissão à lógica do mercado. A pandemia nos tem mostrado que já passou da hora de a revertermos.

Para tanto, diz Boaventura de Sousa Santos, é preciso saber falar disso àqueles que são as vítimas maiores da discriminação operada por um sistema econômico calçado no patriarcado e no colonialismo. Até agora, segundo ele, quem soube lhes falar melhor, porque conhecem sua linguagem e aspirações, foram os pastores evangélicos e os radicalistas do Islão. Porém, suas práticas em nada têm ajudado a mitigar o sofrimento das populações. Ao contrário, a Teologia da Prosperidade, reverberada pelos primeiros, e a violência, disseminada pelos segundos, só têm reforçado a lógica espoliativa e a crueldade discriminatória próprias ao sistema neoliberal, ao mesmo tempo que uma pastoral da manutenção tem se mostrado ineficaz frente aos efeitos desse sistema. É preciso que haja uma reflexão mais aprofundada sobre esses efeitos e sobre os meios mais adequados para combatê-los, do contrário a estrutura eclesial estará fadada ao apequenamento numa velocidade proporcional à secularização provocada pela era digital, acrescendo somente a religiosidade individualista e intimista. No horizonte nebuloso que se nos avizinha, os documentos preparatórios para o Sínodo da Amazônia parecem nos apresentar algumas promissoras e boas iniciativas para afrontá-los. 


\section{Sínodo da Amazônia: aurora de uma resposta criativa à crise geral}

Na contramão dessa lógica, numa época pré-pandemia, tivemos o Sínodo da Amazônia. Tanto o Documento Preparatório (DP) quanto o Instrumentum Laboris (IL) procuraram mostrar a situação calamitosa pela qual passam os povos amazônicos (indígenas e ribeirinhos) e a biodiversidade na qual estão inseridos, por causa do desmate das florestas, do derrame de petróleo, do uso indiscriminado de agrotóxicos e dos rejeitos da mineração legal e ilegal. Infelizmente, o legado de projetos colonizadores, insensíveis à riqueza cultural desses povos, só colaborou para inferiorizá-los e demonizá-los (Cf. DP, n. 4). No discernimento para uma conversão pastoral e ecológica, à luz da Encíclica Populorum Progressio de Paulo VI e da Exortação Apostólica Evangelii Gaudium do Papa Francisco, o DP aponta para a necessidade de se trabalhar "um desenvolvimento integral para todas as pessoas e para a pessoa toda" (n. 8). Amparando-se na Encíclica Laudato Si', as dimensões sacramental e missionário-eclesial, aludidas no DP, fazem ver como "a Eucaristia constitui a comunidade - uma comunidade peregrina festiva, que se torna 'fonte de luz e motivação para as nossas preocupações pelo meio ambiente, e leva-nos a sermos guardiões da criação inteira"” (LS 236). Ao mesmo tempo em que o sangue de tantos homens e mulheres, "derramado e banhando as terras amazônicas, pelo bem de seus habitantes e do território, se une ao Sangue de Cristo, derramado por todos e por toda a criação" (DP, n. 15).

Quanto ao papel das mulheres nesse contexto, o DP não lhe dá um destaque particular. É no IL, na Terceira Parte, reservada à problemática eclesiológica e pastoral, que notamos uma ênfase dada a elas na estrutura eclesial. O IL faz notar que a presença feminina, com seu carisma e talentos no seio das comunidades, nem sempre é valorizada, o que suscita uma reclamação da parte das mulheres, e registra o pedido de que seja recuperado "o espaço que Jesus reservou a elas", “onde todos/todas cabemos" (IL, n. 129 C1)7. Pede-se que Ihes sejam garantidos espaços mais abrangentes e relevantes na área da formação teológica, catequética, litúrgica e nas escolas de fé e de política. Além da formação, que sejam consultadas e participem nas tomadas de decisão, garantindo a sinodalidade eclesial, cabendo

\footnotetext{
7 Sobre o espaço que Jesus reservou às mulheres nas parábolas, por exemplo, consultar nosso artigo: OTTAVIANI, Edelcio \& PATUZZO, Isabella. Discipulado Feminino e Resistência no Papado de Francisco. Encontros Teológicos, v. 35, n. 1, p. 45-51, jan./abr. 2020.
} 
um esforço para identificar o tipo de ministério oficial que pode ser conferido à mulher, levando em consideração o papel central que hoje ela desempenha na Igreja amazônica. Tais reivindicações se apresentam como um bom antídoto ao patriarcalismo e ao clericalismo. Antônio José de Almeida - em diálogo com a tradição da Igreja e a Constituição Dogmática Lumen Gentium -, ao constatar que milhares de comunidades católicas só esporadicamente participam da Eucaristia e ao aprofundar o lugar central que ela ocupa na caminhada do Povo de Deus, aponta para a possibilidade não só da ordenação diaconal como também da ordenação presbiteral para as mulheres. Amparando-se de estudos bíblicos recentes e das fontes patrísticas, relatando a associação existente entre presidência da comunidade e presidência da Eucaristia; pautado na constatação de que não são poucas as comunidades amazônicas presididas por mulheres, Almeida apresenta as razões que poderiam ir ao encontro da crescente demanda pela ordenação presbiteral das mulheres (2019, p. 604) e faz um apelo aos padres atuais para que possam compreender a necessidade de abrir o espaço a essas novas possibilidades ministeriais, sublinhando o papel destes últimos, enquanto celibatários, de garantia da qualidade da formação:

O presbítero celibatário goza de uma "liberdade e disponibilidade no ministério pastoral" que o presbítero casado não tem. A eventual introdução de presbíteros casados nos presbitérios diocesanos ensejaria uma virtuosa redefinição de papéis: os padres celibatários poderiam, por um lado, vir a se dedicar a serviços de nível diocesano e, por outro, a atividades de assistência, acompanhamento, formação, assessoria nos decanatos, paróquias e comunidades infra diocesanas. (ALMEIDA, 2019, p. 607).

Segundo ele, uma tal abertura possibilitaria que a Igreja da Amazônia passasse de uma "Igreja de visita" a uma "Igreja de Presença". Não obstante suas ousadas reflexões no campo pastoral-ministerial, este apelo aos presbíteros celibatários denota ainda que a Igreja se fez refém do poder pastoral por eles exercidos, numa cadeia de sujeição que vai da Santa Sé ao padre situado na mais distante comunidade da Região amazônica. O povo de Deus deseja avançar, mas há algo que faz com que este avanço, nem bem iniciado, comece a emperrar. É o que se entrevê na Exortação Pós-Sinodal "Querida Amazônia" (QA). No tocante à Eucaristia, o documento recua e diz que "não se trata apenas de facilitar uma presença maior de ministros ordenados que possam celebrar a Eucaristia" (n. 93), contradizendo o que diz o Catecismo da Igreja Católica, ao afirmar que "A 
celebração dominical do Dia e da Eucaristia do Senhor está no coração da vida da Igreja" (n. 2177). Em dissonância com o IL, QA desvia da reivindicação proposta pelos documentos de trabalho anteriores, ao dizer que o reducionismo de uma compreensão da Igreja a meras estruturas funcionais levaria o povo de Deus a pensar "que só se daria às mulheres um status e uma participação maior na Igreja se lhes fosse concedido o acesso à Ordem Sacra" (QA, n. 101). QA oferece somente uma interpretação teológica determinando os papéis masculino e feminino no interior da mesma, correspondente ao poder do Senhor em dois rostos humanos: o do Cristo feito homem e de Maria, representando a Igreja, mistério do Esposo da comunidade que celebra a Eucaristia. No entanto, O DP e o IL mostram que há outras vozes na Igreja, além daquela que defende com unhas e dentes as prerrogativas do poder pastoral e um papel secundário à mulher.

Por mais que o Papa Francisco tenha se esforçado em promover o discipulado de iguais, ao colocar algumas mulheres em postos de direção na Santa Sé, é sabido que, em nossas estruturas eclesiais, os postos de decisão foram sendo paulatinamente fechados a elas durante os papados de João Paulo II e Bento XVI, ainda que em um determinado momento thes tenham sido abertos na década seguinte ao Concílio. A contar o caráter articulado das microestruturas de poder ligadas ao governo Central da Cúria Romana, é notável o recuo da presença feminina à frente das estruturas acadêmicas e eclesiásticas. Nesse contexto, o Papa Francisco, ao invés de estar sofrendo resistência por parte dos defensores do poder clerical, é o grande resistente à frente de uma estrutura de poder patriarcal e conservadora, que há centenas de anos se amparou na Santa Sé. Isto é o que procuramos mostrar em nosso artigo "Discipulado feminino e resistência no

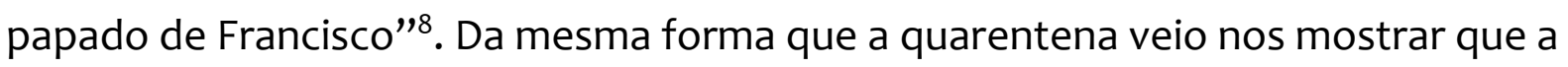
única saída ao modelo neoliberal até o momento é a volta ao Estado de Bem-estar social e à Comunidade acima da lógica do mercado, parece que a única forma de a Igreja não recuar em sua mensagem de Salvação, e de retomar a alegria do anúncio do Evangelho (Evangelii Gaudium), é instaurar um processo de descentralização do poder, de colocar-se em processo de missão e fugir das tentações de sua autopreservação (Cf. BESEN, 2014, p. 166). No próximo tópico, ao abordar as

\footnotetext{
${ }^{8}$ Cf. nota 3. Os resistentes não são os Sarah, Müllers ou Viganòs, mas o Papa Francisco. É o que mostra Marco Politi em seu livro Francesco tra i lupi (2016).
} 
características do beguinato, queremos trazer à tona as consequências nefastas do poder clerical sobre a ação das mulheres na estrutura eclesiástica, comprometendo o futuro da Igreja e o projeto eclesial de evangelização proposto pelo Papa Francisco. Valorizar atitudes semelhantes às dessas mullieres beatae e tendo por luz as reflexões presentes no Documento Preparatório, no Instrumentum Laboris e na Exortação Pós-Sinodal ao Sínodo da Amazônia, parece-me um bom começo de vencer o ocaso da Igreja e ir em direção a uma nova aurora, transformando-a verdadeiramente num Hospital de Campanha, fazendo frente aos mecanismos de sujeição do poder pastoral.

\section{O movimento beguinal à luz das análises contemporâneas de José Comblin e Michel Foucault}

Por caminhos diversos e seguindo a linha de suas respectivas pesquisas, Comblin e Michel Foucault acabaram por analisar as características do movimento beguinal em sua vertente feminina na Baixa Idade Média e seus embates com o poder patriarcal (civil e pastoral), dentro e fora da estrutura eclesial. Se Comblin se ateve ao aspecto luminoso da espiritualidade desenvolvida nos "Béguinages" e ao caráter profético de seu modus vivendi, tanto nos ambientes religiosos quanto na sociedade civil, Michel Foucault o analisa como movimento de contraconduta fazendo frente às garras do poder pastoral. Comblin disserta sobre o poder clerical no décimo capítulo do livro O Povo de Deus (COMBLIN, 2002, p. 354-408) e Michel Foucault trata do poder pastoral, poder sobre todos e cada um (Omnes et Singulatim) em seu Curso Segurança, Território, População (FOUCAULT, 2008, p. 181252), ministrado no Collège de France nos primeiros meses de 1978.

Movido pelo mesmo espírito que animou João XXIII, ao ler os sinais dos tempos num sentido contemporâneo, segundo os critérios do filósofo Giorgio Agamben, Comblin se volta para o movimento beguinal na esperança de que o "ontem", tocado pelo "hoje", ofereça a luminosidade necessária para "responder às trevas do agora" (Cf. AGAMBEN, 2009, p. 72). O olhar retrospectivo de Comblin sobre as beguinas não é saudosista. Ele não lamenta algo perdido e que jamais poderá ser revivido. Ao contrário, seu olhar generoso, movido por uma capacidade ímpar de perscrutar a luta pela justiça nos diferentes períodos da história, nos oferece um panorama daquilo que foi inovador no movimento beguinal, e que não 
pôde ser assimilado no passado por causa do patriarcalismo que impera na estrutura eclesial, e aponta para os efeitos nocivos do poder pastoral (clerical) sobre as inovações femininas no processo de evangelização. Os estudos de Michel Foucault sobre as beguinas, por sua vez, vão ao encontro das análises de Comblin a respeito do caráter resistente e corajoso do movimento beguinal, diante das limitações impostas pelo que ele denomina "poder pastoral”. No Curso Segurança, Território, População (1977-1978), a contemporaneidade do filósofo francês se manifesta nos resultados de seus estudos sobre os diferentes modos de biopoder ao longo do tempo e nas análises dos movimentos que lhes resistiram ao longo da história. Nesse curso, Foucault aborda as características do poder pastoral (poder sobre todos e cada um - Omnes et Singulatim), bem como os elementos que deram origem à sua crise, no final do século XVI. Segundo ele, o poder pastoral, após as contestações dos movimentos espirituais e da Reforma, explodiu e se dispersou, dando vazão às técnicas de governamentalidade do Estado Moderno. Na origem dessa dispersão, Foucault detectou formas de ataque e de contra-ataque que foram produzidas no próprio campo do pastorado, denominadas por ele 'movimentos de revoltas específicas de conduta' (FOUCAULT, 2008, p. 266-267). Dentre esses, encontra-se o movimento das beguinas, cuja irreverência para com os ditames do matrimônio e da vida monástica problematizou o estatuto da mulher na sociedade medieval, tanto em âmbito civil quanto religioso.

Ao visitarem o arcaico, segundo a interpretação de Agamben (Cf. 2009, p. 70), Comblin e Foucault notam no movimento beguinal elementos que podem ser a arché, o principium, a origem, a inspiração de algo novo, tal como se busca, no mundo da moda, visitar o passado para nele buscar um conceito capaz de instaurar um "não mais" e um "ainda não", reevocando e revitalizando aquilo que fora até mesmo declarado morto (AGAMBEN, 2009, p. 69).

\section{Características proféticas do movimento beguinal, segundo Comblin, e de contra- conduta, segundo Foucault}

No Brasil, pouco se fala sobre as beguinas e, mesmo no meio acadêmico, nota-se nos semblantes certa surpresa quando falamos delas. Na Europa, as paredes seculares dos béguinages ainda atestam a sua presença na história, mas o termo "béguines", ao longo do tempo, passou a receber uma conotação pejorativa, 
servindo de expressão para designar pessoas pouco letradas e com certo grau de inocência, quem sabe de imbecilidade (Cf. PANCIERA, 2009, p. 31). No entanto, os estudos que atualmente são feitos sobre os béguinages mostram em sua origem a presença de mulheres cultas e ousadas (parresiastas) ${ }^{9}$, que traduziam a Bíblia em língua vernácula e a comentavam entre aqueles que eram escopo de sua caridade: leprosos e doentes de peste negra, órfãos e viúvas de combatentes em guerras e cruzadas. Em O Povo de Deus (COMBLIN, 2002, p. 354-408), Vocação à Liberdade (COMBLIN, 1998, p. 125-129) e O Espírito Santo e a Tradição de Jesus (COMBLIN, 2012, p. 80-81; 337-338), Comblin discorre sobre as coerções operadas pela hierarquia e as condenações de Clemente V e do Concílio de Vienne (França - 1312), ao declarar as beguinas como hereges (COMBLIN, 2008, p. 148), por meio da bulas Cum de Quibusdam Mulieribus (1305) e Ad Nostrum Qui (1314). Tais condenações acabaram por estigmatizá-las e por minimizar seu valor na história eclesiástica, embora não tivessem conseguido exterminá-las na Alta Renânia, por causa de seu caráter exemplar em contraste com o modo de vida lascivo de boa parte dos clérigos.

Em O Espírito Santo e a Tradição de Jesus, Comblin afirma que o movimento das beguinas nasce como resultado de uma série de fatores: em primeiro lugar, em decorrência das comunas medievais, nas quais os representantes das atividades artesanais procuraram emancipar-se da dominação dos bispos e dos nobres (COMBLIN, 2012, p. 139-140); em segundo lugar, dos movimentos populares "A Paz de Deus" e a "Trégua de Deus" que protestaram, no século XI, contra o espírito guerreiro e espoliativo dos cavaleiros medievais. "A Paz e a Trégua de Deus" levaram as massas rurais a compreender que, unidos, podiam ter força para se oporem aos que os escravizavam (COMBLIN, 2008, p. 122); em terceiro, dos movimentos espirituais que proclamavam, em oposição à riqueza e à corrupção do alto clero e da nobreza, um retorno às fontes do Evangelho, numa adesão ao Cristo pobre e compassivo. Gioacchino da Fiore (1132-1202) influenciou profundamente esse tempo quando escreveu que a história estava dividida em três partes: antes de Jesus, fora a

\footnotetext{
${ }^{9}$ Em A Coragem da Verdade, curso ministrado no Collège de France em 1984, Michel Foucault trata da parresía (franco-falar, coragem da verdade) e sua dimensão política. No último capítulo, ao tratar da parresía na tradição cristã, mostra como a compreensão em Paulo, e dos mártires cristãos, está muito próxima da compreensão da tradição helênica do século VI a.C: o risco de afrontar as determinações do tirano (FOUCAULT, 2011, p. 290). Por afrontar a inquisição por causa de sua experiência interior, a béguine Marguerite Porete será queimada viva pelo braço secular depois de ser condenada pela inquisição, por causa de seu livro: Les Miroirs des âmes Simples et Anéanties et qui seulement demeurent en vouloir et désir d'Amour (1305).
} 
Idade do Pai; com Jesus, tem início a idade do Filho; e estava para nascer a era de uma Igreja espiritual, sem dominação, sem riqueza, sem poder. Muitos viram em Francisco de Assis o iniciador dessa era do Espírito (COMBLIN, 2008, p. 141).

Foucault, da mesma forma, vê no movimento beguinal, como em outros que apresentam a mesma irreverência, um traço de revolta contra a soberania dos nobres e dos religiosos que exploram economicamente os que governam (2008, p. 257), mas não o associa aos seus estudos sobre a parresía (Curso Coragem da Verdade (1984), onde ele distingue a palavra do parresiasta daquela dos sábios e dos profetas). A esses movimentos de resistência específica, Foucault atribui o nome de movimentos de contraconduta, cuja resistência se opõe a certa maneira de governar. Essa atitude irreverente se expressa por um "querer ser conduzido de outro modo, por outros condutores, por outros pastores, para outros objetivos e para outras formas de salvação, por meio de outros procedimentos, de outros métodos. São movimentos que também procuram, eventualmente, em todo caso, escapar da conduta dos outros, que procuram definir para cada um a maneira de se conduzir" (2008, p. 257). Comblin, por sua vez, destaca o caráter profético do movimento, que em sua quase totalidade não rejeitava a instituição eclesiástica, mas pregava a renovação da mesma pelo exercício da liberdade e do serviço aos pobres. Esta ousadia não passou ilesa pela hierarquia e pela aristocracia, cujas pressões sobre as beguinas iam da calúnia à ridicularização.

\section{Práticas e escritos desenvo/vidos pelas beguinas enquanto resistência aos assaltos do poder pastoral}

O movimento beguinal surge nesse período, aproximadamente no final do século XII. Vários autores apontam Nivelles, na Bélgica, como o seu lugar de nascimento, outros em Liége, geralmente baseados nos escritos que o citam pela primeira vez. Ele surge, portanto, na Walônia e se expande rapidamente nos Países Baixos e cresce vertiginosamente pela Alemanha, França e norte da Itália. É formado primeiramente por mulheres, denominadas mullieres religiosae ou devotae. No âmbito eclesial, por causa da proibição de serem criadas novas ordens religiosas decretada pelo cânon 13 do IV Concílio de Latrão (1215), a exceção dos frades pregadores, menores, carmelitas e agostinianos (Cf. SCHIMITT, 1978, p. 59), um grupo de mulheres, desejosas de se consagrarem integralmente no serviço aos 
pobres e aos doentes, e vendo-se viúvas ou órfãs sem querer se submeter aos ditames da vida conjugal, encontrou da parte de alguns bispos a simpatia de criar um espaço para que pudessem viver em comunidade para a prática da oração e das obras de caridade. Esse foi o caso do bispo Jacques de Vitry, que conseguiu do papa Inocêncio III, em 1216, a permissão de criar esses espaços de convivência em sua diocese. Quanto ao nome, e nisto Comblin e Foucault estão de acordo, não se sabe ao certo qual a razão, pois muitas são as hipóteses apresentadas, não havendo nenhuma que encontre uma prova evidente.

Morando em pequenas comunidades, formadas por certo número de casas independentes, as beguinas possuíam bens e não estavam comprometidas ao mesmo rigor da vida religiosa, embora vivessem modestamente. Essas propriedades, independentes uma das outras, mas cercadas por um muro, não podiam ser vendidas nem passadas para seus familiares. Elas estavam sob a tutela de um curador e, no caso de morte de uma beguina ou mais beguinas, só poderiam ser ocupadas por outras. Cada casa tinha um ato de fundação ou uma regra constituída pouco a pouco, que impunha às beguinas um modo de vida determinado. As beguinas dependiam do Magistrado local e não gozavam de imunidade fiscal, devendo arcar com as taxas municipais. Cada comunidade tinha uma superiora, denominada martha, magistral ou meisterin. A obediência à superiora era requisitada, sob pena de expulsão. Como diz Jean-Claude Schimitt, nos béguinages as preocupações morais eram determinantes. As candidatas admitidas deviam fazer prova de uma castidade irreprovável. Elas eram obrigatoriamente viúvas ou celibatárias. Em geral não eram admitidas mulheres muito jovens, mas em Colônia havia registro de meninas de 14 ou até mesmo de 12 anos (Cf. SCHIMITT, 1978, p. 51, nota 40). Podiam, no entanto, sair quando quisessem para se casar.

Dos pontos de vista social e eclesial, o que se destaca mais nesse movimento é o desconcerto que elas causavam no âmbito civil, por escaparem do matrimônio, que consolida o direito do homem sobre a mulher, e no religioso, por recusarem a vigilância dos diretores espirituais aos quais estavam submetidas quase todas as comunidades religiosas femininas. Presentes nos leitos dos doentes, as beguinas pouco a pouco foram também se encarregando de todas as cerimônias de exéquias. No século XIV, era comum deixar em testamento uma soma em dinheiro para as beguinas para que providenciassem as velas e orassem pelo legatário em seu 
aniversário de morte. Assim, era-lhes atribuída uma função social importante. Porém, essa intimidade com a morte, da mesma forma como angariava respeito, inspirava temor. A polêmica em torno ao estatuto ambíguo das beguinas também saberia tirar partido deste fato. Logo se fariam as associações: temor - medo - suspeita - heresia.

Embora a austeridade de sua vida piedosa, dedicada aos doentes, órfãos e pobres tivesse angariado, no início, o respeito e a simpatia das populações urbanas, pouco a pouco, seu estatuto de celibatárias, a meio caminho entre a vida laica e religiosa, foi alvo de maledicentes suspeitas. Independentes no que concerne às regras canônicas e ao domínio patriarcal, as beguinas eram também independentes do ponto de vista econômico, pois não pediam esmolas, como os mendicantes, nem doações, como as ordens religiosas, mas viviam tão somente de seu próprio trabalho. Teciam, bordavam e tingiam roupas. Uma inovação também marcante do movimento está no fato de elas terem oferecido às mulheres uma via "popular" ao engajamento religioso. O mestre franciscano Guibert de Tournai (1200-1284), às vésperas do Concílio de Lyon (1274), se inquietava que em sua diocese havia:

Mulheres chamadas béguines, que se vangloriam de suas sutilezas e se alegram das novidades. Elas interpretaram os mistérios da Escritura e os traduziram em francês, ao passo que aqueles que são verdadeiramente versados em seu estudo não os penetram senão com dificuldade. Elas os leem juntas, sem respeito, com audácia, nos conventinhos, nas celas obscuras, sobre as praças públicas (apud PANCIERA, 2009, p. 23).

No curso Em Defesa da Sociedade (1975-1976), Foucault procura mostrar como a história até a Idade Média esteve a serviço da legitimação do poder dos soberanos. Durante muito tempo, como dizia Petrarca (1304-1374), a história dos reinados foi sempre a história de Roma, dos vencedores (FOUCAULT, 2005, p. 86). Com a leitura em língua vernácula da Bíblia, as beguinas, assim como todos os que traduziam e comentavam as Escrituras em praça pública, apresentaram ao povo uma contra-história, a história dos judeus, a história dos vencidos. Por meio dela, os pobres começaram a compreender que há muita sujeira e muita corrupção no exercício do poder e que este tipo de governo, como diziam os profetas, não está de acordo com a vontade de Deus. Como diz Foucault, "jamais se deve esquecer de que a Bíblia foi, a partir da segunda metade da Idade Média pelo menos, a grande forma na qual se articularam as objeções religiosas, morais, políticas, ao poder dos reis e ao despotismo da Igreja" (FOUCAULT, 2005, p. 83). 


\section{Conclusão}

Embora pudéssemos dedicar mais tempo à descrição do que caracterizava o movimento das beguinas, as análises de Comblin e Foucault, complementadas por outros autores, nos ofereceram uma visão panorâmica de seus principais elementos. Por meio dela, pudemos perceber como as tentativas de um estatuto diferenciado da mulher foram insistentemente obliteradas pelo patriarcalismo tanto na sociedade civil quanto na Igreja, não obstante a resistência das beguinas em permanecer no seio desta última por mais de oitocentos anos (a última beguina faleceu na segunda década do século XXI). As inovações inauguradas por elas deixaram marcas profundas na tradição católica e protestante, como por exemplo a linguagem amorosa para falar com Deus e sobre Deus, testemunhada pelas místicas ${ }^{10}$; a tradução e o comentário das Sagradas Escrituras em língua vernácula e os meios mais lúdicos para falar de Deus aos pobres, além de uma assistência incansável aos mais desvalidos. Elas incomodaram porque, ao traduzir as Sagradas Escrituras e ao comentá-las, ofereceram aos pequenos (servos e iletrados) a oportunidade de conhecerem os critérios evangélicos e de discernirem os bons dos maus pastores, a ponto de dizerem a estes: "não desejamos ser conduzidos dessa forma, não aceitamos ser governados desse jeito, não reconhecemos esse regime de verdades". Resgatar o modus vivendi das beguinas, reatualizar suas práticas e deixar-se motivar por elas, associando-as às iniciativas propostas pelos documentos preparatórios ao Sínodo da Amazônia, pode ser o início de um novo estatuto da mulher na Igreja e, com ele, a abertura de espaços para práticas promissoras de evangelização, presenciais e até mesmo virtuais, dentro e fora das estruturas eclesiais, e que apontem saídas para a crise exponencial em que nos encontramos, à luz da práxis libertadora de Jesus. Oxalá se multipliquem os Jacques de Vitry e, por meio deles, junto às mullieres religiosae de nosso tempo, institua-se um discipulado de iguais capaz de interceptar o colonialismo e o patriarcalismo, que dão sustentação ao sistema injusto em que vivemos.

\footnotetext{
${ }^{10}$ Lutgarde d`Aywières, Béatrice de Nazareth, Christine de Saint Tronde e Marguerite Porete.
} 


\section{Referências}

AGAMBEN, G. O que é o contemporâneo? E outros ensaios. Trad. Vinicius Nicastro Honesko. Chapecó: Argos, 2009.

ALBUQUERQUE, J. Susan Sontag acertou ao denunciar metáfora que compara doença a guerra. Folha de São Paulo, 21 abr. 2020. Disponível em: https://www1.folha.uol.com.br/colunas/juliana-de-albuquerque/2020/04/susan-sontagacertou-ao-denunciar-metafora-que-compara-doenca-a-guerra.shtml?origin=uol. Acesso em: 10 mai. 2020.

ALMEIDA, A. J. Milhares de comunidades sem eucaristia interpelam o Sínodo da Amazônia. Pistis e Práxis, Curitiba, v. 11, n. 3, p. 585-616, set./dez. 2019.

BESEN, J. A. Evangelii Gaudium, Lumen Fidei. A Alegria do Evangelho é a Luz da Fé: Interpelações do Papa Francisco para a Igreja de hoje. Encontros Teológicos, n. 67, ano 29, n. 1, p. 151-171, 2014.

COMBLIN, J. Vocação para a Liberdade. São Paulo: Paulus, 1998.

COMBLIN, J. O Povo de Deus. 2. ed. São Paulo: Paulus, 2002.

COMBLIN, J. A Profecia na Igreja. São Paulo: Paulus, 2008.

COMBLIN, J. O Espírito Santo e a Tradição de Jesus. São Bernardo do Campo: Nhanduti, 2012. (Obra Póstuma)

DOCUMENTOS DO CONCÍLIO VATICANO II. Lumen Gentium [LG]. 2. ed. São Paulo: Paulus, 2002a. p. 101-197.

DOCUMENTOS DO CONCÍLIO VATICANO II. Sacrosanctum Concilium [SC]. 2. ed. São Paulo: Paulus, 2002b. p. 33-79.

FOUCAULT, M. Em Defesa da Sociedade. Curso ministrado no Collège de France de 19751976. Maria Ermantina Galvão. São Paulo: Martins Fontes, 2005.

FOUCAULT, M. Segurança, Território e População. Curso no Collège de France (1977-1978). Trad. Eduardo Brandão. São Paulo: Martins Fontes, 2008.

FOUCAULT, M. A Coragem da Verdade. Curso ministrado no Collège de France em 1984. Trad. Eduardo Brandão. São Paulo: Martins Fontes, 2011.

FRANCISCO, Papa. Gaudete et Exultate: exortação apostólica sobre a chamada à santidade no mundo atual. São Paulo: Paulinas, 2019. (Doc. 206).

FRANCISCO, Papa. Carta do Papa aos Presbíteros por ocasião dos 160 anos da morte do Cura D’Ars. Disponível em: http://www.vatican.va/content/francesco/pt/letters/2019/documents/papafrancesco_20190804_lettera-presbiteri.html. Acesso em: 21 mai. 2020. 
JOÃO PAULO II (promulgou). Catecismo da Igreja Católica [CAT]. São Paulo: Loyola, Vozes, Salesiana, Paulinas, Ave-Maria, Paulus, 1999.

LUCIANI, R. (SJ). Es la hora de ayunar del Pan y aprender a comulgar con la Palabra. In VVAA. Covid 19. S.I.: MA-Editores, 2020. p. 21-28.

MERKEL, A. Discurso al pueblo alemán ante la situación del Coronavirus. In: VVAA. Covid 19. S.I.: MA-Editores, 2020. p. 86-93.

OTTAVIANI, E.; PATUZZO, I. Discipulado de Francisco e Resistência no Papado de Francisco. Encontros Teológicos, v. 35, n. 1, p. 45-51, jan./abr. 2020.

PANCIERA, S. Les Béguines. Namur: Fidélité, 2009.

POLITI, M. François parmi les loups. Traduit de l'italien para Samuel Sfez. L'Isle d’Espagnac: Philippe Rey, 2016. (Francesco tra i lupi).

SCHMITT, J.-C. Mort d'une Hérésie. L'Église et les clercs face aux béguines et aux béghards du Rhin supérieur du XIVe au XVe siècle. Paris: Mouton/École des Hautes Études en Science Sociales, 1978.

SECRETARIA GERAL DO SÍNODO PARA A AMAZÔNIA. Documento Preparatório: (DP): "Amazônia: Novos Caminhos para a Igreja e para a Ecologia Integral”. Disponível em: http://www.sinodoamazonico.va/content/sinodoamazonico/pt/documentos/documentopreparatorio.pdf. Acesso em: 10 mai. 2020.

SÍNODO DOS BISPOS ASSEMBLEIA ESPECIAL PARA A REGIÃO PAN-AMAZÔNICA. Amazônia: Novos Caminhos para a Igreja e para a Ecologia Integral: Instrumentum Laboris (IL). São Paulo: Paulinas, 2019. (Documento 52).

SOUSA SANTOS, B. A Cruel Pedagogia do Vírus. Coimbra: Almedina, 2020.

SPADARO, A. (SJ). Entrevista exclusiva do Papa Francisco. São Paulo: Paulus; Loyola, 2013.

VIGANÒ, C. M. et al. Apelo para Igreja e para o Mundo. 7 mai. 2020. Disponível em: http://www.diesirae.pt/2020/05/apelo-para-igreja-e-para-o-mundo.html. Acesso em: 22 mai. 2020.

RECEBIDO: 30/05/2020

RECEIVED: 05/30/2020

APROVADO: 02/12/2020

APPROVED: $12 / 02 / 2020$ 